\title{
System Dynamics Modelling of Railway Electrification in Latvia
}

\author{
Liga ROZENTALE ${ }^{1 *}$, Gjermund Bjørseth $\mathrm{MO}^{2}$, Armands GRAVELSINS ${ }^{3}$, Claudio ROCHAS $^{4}$, \\ Jelena PUBULE ${ }^{5}$, Dagnija BLUMBERGA ${ }^{6}$ \\ ${ }^{1,3-6}$ Institute of Energy systems and Environment, Riga Technical University, Azenes iela 12/1, \\ Riga, LV-1048, Latvia \\ ${ }^{2}$ Western Norway University of Applied Sciences, Inndalsveien 28, 5063 Bergen, Norway
}

\begin{abstract}
Nowadays the transport sector is one of the most challenging sectors in terms of reducing pollution produced in this sector. It becomes more and more clear that one of the best solutions for mitigating this pollution and the climate change linked to it is the usage of electrified railway. The aim of this article is to evaluate the impact that electrification of the railway will have on the environment from the perspective of pollution. The article shows a system dynamics model, which is based upon factors that affect a newly electrified railway. These include power demand, economics and the environmental impact originating from the railway. This model can be applicable for any country, however in this article Latvia is modelled as an example of how the model works and how the environmental factors will change as a result of an electrification of Latvia's railway system.
\end{abstract}

Keywords - Climate change; electricity policy; environmental impact; railway electrification; renewable energy sources; system dynamics

\section{INTRODUCTION}

The European Commission (EC) has pointed out that mobility of goods is an essential part of the European Union's (EU) internal market and is crucial for the competitiveness of European industry and services. It has a significant impact on economic growth and job creation. In recent years, the annual volume of inland freight transport in the EU (including road, rail and inland waterways) has stabilized at around 2300 billion tonne-kilometres per year, and road transport accounts for about $75 \%$ of this total. [1]

With regard to Latvia, it should be noted that transport and logistics are the second largest sector of the economy, generating more than one billion euros of revenue to the state budget or one eighth of the total state budget and employing up to 70 thousand people directly or indirectly.

Railway transport is one of the most promising modes of land transport, both in safety and in environmental terms. Of the country's total land transport, the share of rail freight is approximately $39 \%$ (as shown in Fig. 1), while passenger transport is $7 \%$. In the structure of rail freight transport $85 \%$ is transit traffic, mainly from Russia and Belarus to ports in Latvia (East-West transit corridor), inland transport is about $11 \%$ [1].

* Corresponding author.

E-mail address: liga.rozentale@em.gov.lv 


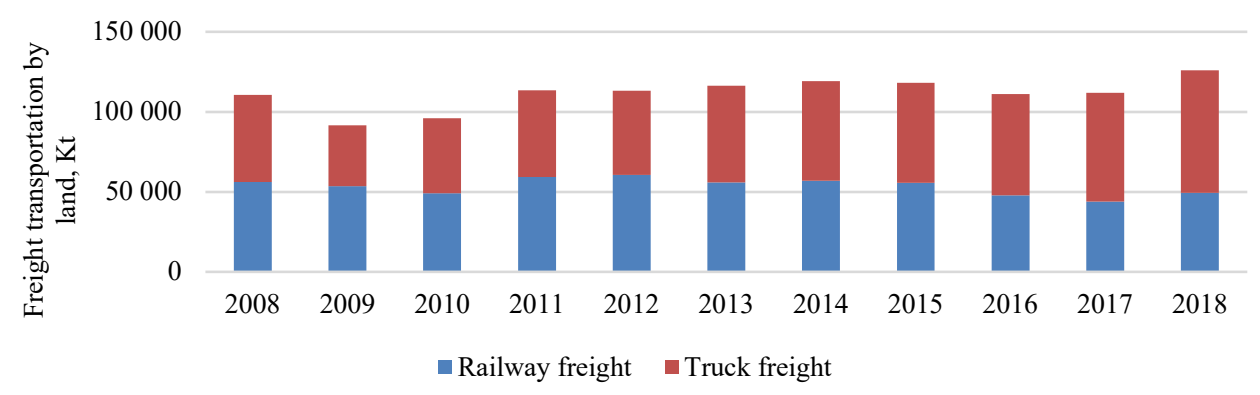

Fig. 1. Freight transportation by land in Latvia [2].

The total length of Latvia's rail network is about $1860 \mathrm{~km}$, of which only about $14 \%$ is electrified (this is substantially lower than the EU average of $55 \%$ ). However, at present, electric trains can only be used for passenger transportation, while freight is only carried by diesel trains [3].

The EC has also noted that the transport sector has a negative impact on the environment and the quality of life of EU citizens. The transport sector accounts for about one third of energy consumption and total $\mathrm{CO}_{2}$ emissions in the EU. Promoting efficient and sustainable transport modes such as rail and inland waterways could help in reducing Europe's dependence on imported oil and reduce pollution [4]. According to the European Environment Agency and as shown in Fig. 2, rail transport produces 3.5 times less $\mathrm{CO}_{2}$ emissions per tonne-kilometre than road transport [1].

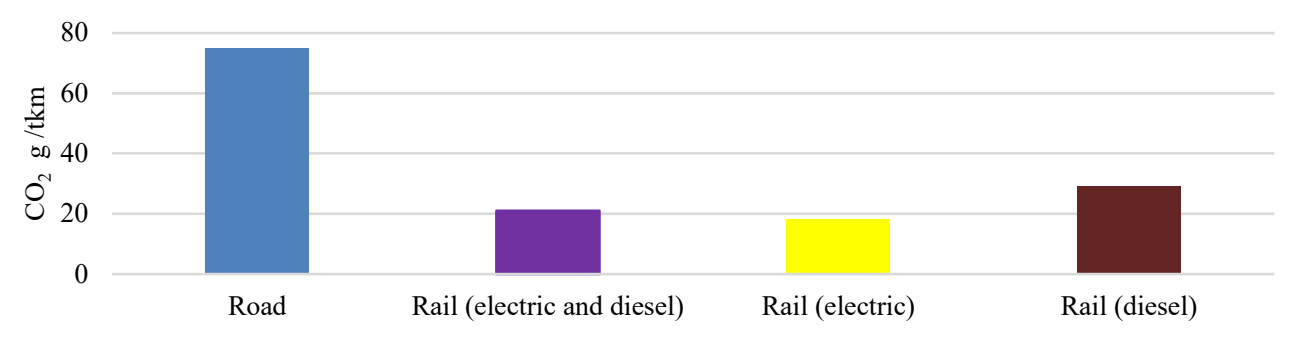

Fig. 2. $\mathrm{CO}_{2}$ emissions per tonne-kilometre in the $\mathrm{EU}[4]$.

However, currently diesel is the main energy source both for truck and railway freight, which is also the main source of emissions (mostly $\mathrm{CO}_{2}$ ) in the land transport sector.

The promotion of more efficient and sustainable modes of transport, in particular rail freight, has been an essential element of EU policy for the last 25 years. Already in 1992, the EC set itself the prime objective of achieving a balance between the various modes of transport. In 2001, it reaffirmed the importance of revitalizing the rail sector and set the objective of maintaining rail freight at a $35 \%$ level in the Member States of Central and Eastern Europe by 2010. Finally, in 2011 , the EC set a target for 2030 to shift $30 \%$ of road freight transport with a route longer than $300 \mathrm{~km}$ to other modes, such as rail or waterways, and by 2050 to shift $50 \%$ [1], [6].

Dependent on the available resources, every country in the regions of Scandinavia and the Baltics are aiming towards the same goal of the EU to decrease the outlet of greenhouse gases 
(GHG) with $20 \%$ by 2020 [7] and to reduce $\mathrm{CO}_{2}$ emissions by $80 \%$ within 2050 [8], as well as to reach the goal of the Paris agreement [7]. This change towards a more sustainable feeding-system for the railway will demand severe resources and cooperation across borders.

There is a reason to believe that the electrification of the railway will have a major positive impact on the economy and a reduction of the emissions originating from the railway. Countries that have implemented electrical railways have generally had an increase in the economy and decrease of emissions coming from the transport sector. It is not only expected to benefit the country at a national level but also in the rural areas, which might experience an increase in tourism and industries. While the developed model is extensive and allows to evaluate railway electrification from different perspectives, including country's economy as a whole, this article focuses on the environment and the main objective of this article is to research how the electrification of the railway will affect the environment from the perspective of pollution.

For system dynamics modelling purposes, the modelling tool Stella Architect has been utilized as this is a great tool for simulations and forecasting of different dynamic scenarios. The authors of the article use this programme to develop a scenario that is appropriate for countries that might want to change the fuel source from fossil to electrical power in regard to the specific country's situation.

\section{Methods ANd Procedures}

\subsection{Model development}

Modelling is defined as an imitation of real-life situation with mathematical equations in order to forecast the future developments of a situation. It is an analytical instrument, which allows to quantify the aspects that may affect the environment. Computer models are often used to forecast the chemical or physical impact of an action on the environment. A model can aid in explaining the environment as a linked system and to research the impact of different environmental components as well as to give forecasts on their behaviour [9]. There are different approaches for modelling, but this particular research is focused on system dynamic modelling, which is an approach to figuring out the nonlinear behaviour of complex systems over time using stocks, flows, internal feedback loops, table functions and time delays [10], [11].

To understand the impact electrification has on the environment as well as the energy supply and production, the model considers the current situation of the electrical supply system and the future development of the system. In the model there are four main factors that must be considered:

- emissions;

- power usage;

- transport opportunities;

- economic influence.

These factors are implemented into the hypotheses. The hypotheses influence each other through the whole simulation period, where the inputs are integrated into the hypotheses before they are further directed into the main model which shows the results.

The model contains a private sector scenario and a government ownership scenario; scenarios can be switched on and off to compare the different results and to understand and compare the benefits of each specific sector, whereby each has its own potential. Each scenario includes the appropriate parameters for the specific scenario. The model also includes such state policies as implementation of railway electrification project and switching from fossil to renewable energy sources. 
As the model is built upon several parameters, which can be utilized in any country that considers electrification of the railway, this model is made around a fluent structure, where it is possible to add different scenarios suited for the use of the model. In this model, the main suitable parameters of a private/government owned railway are incorporated to simulate the influence that different scenarios might have on the economy and environment.

In this model the variables influencing the pollution are defined as Pollution units. This covers all the current pollution factors - carbon dioxide $\mathrm{CO}_{2}$, sulphur dioxide $\mathrm{SO}_{2}$, nitrogen oxides $\mathrm{NO}_{x}$, methane $\mathrm{CH}_{4}$ and particulate matter PM. The reason for these being made in to one unit is to reduce the size of the model and since the overall goal is to be able to observe the pollution from the railway in general these will not affect the model in one way or another.

\subsection{Environmental influences}

The environmental aspects of the model cover the particulate matter (PM) and greenhouse gases (GHG). The sources for these emissions can be found in both railway and the power generation sector. As these sectors operate in two completely different aspects of industry, they are separated in the model as well - the railway is represented by emissions from Korean locomotives, and the power sector has the emissions originating from power production.

Based on Korean research [12], a diesel-electric locomotive produces $282 \mathrm{~g} / \mathrm{kWh}$ emissions when idle and as much as $701 \mathrm{~g} / \mathrm{kWh}$ when at the highest level of performance, $\mathrm{N}_{2} \mathrm{O}$ at $0.0181 \mathrm{~g} / \mathrm{kWh}$ when idle and $0.0107 \mathrm{~g} / \mathrm{kWh}$ at maximum use, and $\mathrm{CH}$ at $0.0394 \mathrm{~g} / \mathrm{kWh}$ when idle and $0.0103 \mathrm{~g} / \mathrm{kWh}$ when at maximum use. Dependent on the activity of the motor the emissions rise, when at maximum output the motors in the mentioned Korean research used as much as $2363 \mathrm{~kW}$ at notch 8 , which is the highest throttle setting for these locomotives.

This means that a diesel-electric locomotive has an hourly demand of $2363 \mathrm{kWh}$, this results in a maximum hourly carbon dioxide $\mathrm{CO}_{2}$, methane $\mathrm{CH}_{4}$ and nitrous oxide $\mathrm{N}_{2} \mathrm{O}$ emissions as Eq. (1)-(3).

$$
\begin{gathered}
\mathrm{CO}_{2}\left[\mathrm{t} \mathrm{h}^{-1}\right]=701\left[\mathrm{~g} \mathrm{kWh}^{-1}\right] \cdot 2363[\mathrm{kWh}]=1.66\left[\mathrm{t} \mathrm{h}^{-1}\right] \\
\mathrm{N}_{2} \mathrm{O}\left[\mathrm{t} \mathrm{h}^{-1}\right]=0.0107\left[\mathrm{~g} \mathrm{kWh}^{-1}\right] \cdot 2363[\mathrm{kWh}]=25.28\left[\mathrm{~g} \mathrm{~h}^{-1}\right] \\
\mathrm{CH}_{4}\left[\mathrm{t} \mathrm{h}^{-1}\right]=0.0103\left[\mathrm{~g} \mathrm{kWh}^{-1}\right] \cdot 2363[\mathrm{kWh}]=24.34\left[\mathrm{~g} \mathrm{~h}^{-1}\right]
\end{gathered}
$$

These are significant amounts of hourly emissions affecting the local and global environment.

PM in the model is a part of the total emissions in the model as it impacts the model at the same rate as the other emissions.

In the current situation, the feeding of the electrical railway is done by both non-renewable energy and renewable energy, which is how the power network is mostly fed throughout Europe.

With most of the electricity coming from non-renewable power sources, the non-renewable energy must be considered in the model as this is an extremely important part of the current electrical feeding system. 


\subsection{Economical influences}

The economical parameters are divided between the private and government sectors. As the electrical railway is believed to be economically sustainable over time for both sectors, the main indicator of when the proposed project can be called a success is when the project has economical surplus. This is however a larger factor in the private sector than in the government one, as the government sector has more funds to operate the railway over time. It is very important to separate the two sectors and to separate what kind of subsidies they are able to incorporate into the budget for the railway.

For the private sector the main obstacle is the ratio between investments and profit from the railway. To get a high profit from the railway, it is crucial to make it visible for the public and the transport firms, as well as it must be a sensible alternative to road transport. To move the transport of goods from road to railway is not easy as road transport is very popular with cheap labour and relatively low fuel cost compared to the cost of operating a freight train. One huge benefit of electrical railway is the implementation of emission quotas, which over time, will limit the fuel resources that are currently used for road transport unless the energy used is renewable. The road transport sector is currently far behind the railway sector in this regard and there are currently no available options for freight companies to use electrical energy as a fuel supply. This has an extensive impact on the model, which can be highly visible towards the end of the simulation.

The emission quotas themselves are one of the most significant parameters for the model as the prices for them are rapidly increasing over time. Since 2014 , the price has increased by $265 \%$, from $6.84 \mathrm{EUR} / \mathrm{tCO}_{2}$ [13] up to more than $25 \mathrm{EUR} / \mathrm{tCO}$ in the beginning of 2020 [14]. The yearly increase for the model is estimated at $5.58 \%$. This affects the whole model regardless of which sector is run in the model.

Another factor included is the financial stability of the sectors, as the government can take a longer time on the down payment for the railway compared to the private sector which needs annual results that prove the benefits of investment. For both sectors, the goal is to get the railway operations into an economical equilibrium, which will brand it as a success. This is however very difficult to achieve as railway operations require a lot of resources and an even flow of transport. There will be certain delays in the beginning of the railway which will slow the transport down and lead to potential delay in the return of investment from the railway.

Investment costs in the railway will be considered as a negative variable in the model, as this again is used as a measurement for when the railway has reached equilibrium. The initial cost is the same for both scenarios, which in this model is estimated as the cost for a new railway in Latvia.

\subsection{Energy influences}

The energy supply is very important to be able to reduce the pollution when the railway is finished. This will determine if the investment in the railway has led to improvements to the environment or if the situation is still the same.

The current situation used in the model is that the electrical energy is 50/50 in terms of what source the energy originates in. This means that we can assume that the railway is going to be supplied by electricity from both RES and fossil energy.

In the model there is a separate structure that provides a simulation of the energy sector as well as the railway sector. The model does not include the energy demand for the rest of the country, only the demand relevant for the railway. 


\section{Case Study}

While the model can be used for any country to evaluate and understand the challenges and possibilities provided by an electrified railway, this case study shows the adaptation of the model for Latvia' s transport sector.

The environmental variables for the model are shown in Table 1. These variables give better understanding of how the railway may influence the socio-economic aspects of a country; these variables are then further developed towards the objective of the specific simulation.

The emissions from the locomotives are based on how they are operated throughout the year as the operations may differ from year to year. Thus, the operating time is included as well, as they indicate how the increase of emissions may differ depending on the assignments the railway gets.

The total costs in the railway are a result of wages, taxes and fuel costs. With this and the income from the railway, the total revenue is calculated in the model and the model is structured around these revenues as this is the most important measurement for the interested parties.

One very important aspect of the railway investment is the payback time. As this is a major indicator of the investment success, before and after the project is finished. If it takes too long to make the investment a profitable operation, there will be no desire to invest in it.

The corporate income tax seldom changes over time and is therefore set as a stationary value. The wages on the other hand tend to increase every year by a small percentage. This is also the case in regard to fuel price, as they tend to follow the increase of wages.

Table 1 describes the variables for the revenue. This is an outlay for which variables the economic side of the model needs to run functionally.

The model is built around one structure but have several other sub-models such as pollution sub-model, locomotive change sub-model, economic sub-model, hired workers sub-model and energy sub-model, which all support the main model.

\section{TABLE 1. VARIABLES IN THE MODEL}

\begin{tabular}{|c|c|c|c|c|c|}
\hline $\begin{array}{l}\text { Environmental } \\
\text { variables }\end{array}$ & $\begin{array}{l}\text { Revenue } \\
\text { variables }\end{array}$ & $\begin{array}{l}\text { Economic } \\
\text { variables }\end{array}$ & $\begin{array}{l}\text { Pollution } \\
\text { variables }\end{array}$ & $\begin{array}{l}\text { Hiring } \\
\text { variables }\end{array}$ & $\begin{array}{l}\text { Energy } \\
\text { variables }\end{array}$ \\
\hline $\begin{array}{l}\text { Renewable energy } \\
\text { sources }\end{array}$ & $\begin{array}{l}\text { Corporate } \\
\text { tax rate }\end{array}$ & Worker salary & $\begin{array}{l}\text { Pollution from } \\
\text { diesel } \\
\text { locomotives }\end{array}$ & $\begin{array}{l}\text { Assumed birth } \\
\text { rate }\end{array}$ & $\begin{array}{l}\text { Pollution } \\
\text { from fossil- } \\
\text { fuel based } \\
\text { energy }\end{array}$ \\
\hline $\begin{array}{l}\text { Non-renewable } \\
\text { electrical supply }\end{array}$ & Wages & Locomotive cost & $\begin{array}{l}\text { Pollution from } \\
\text { energy sources }\end{array}$ & $\begin{array}{l}\text { Available } \\
\text { workers }\end{array}$ & $\begin{array}{l}\text { Change rate } \\
\text { from fossil to } \\
\text { renewable } \\
\text { energy } \\
\text { sources }\end{array}$ \\
\hline $\begin{array}{l}\text { Locomotive power } \\
\text { demand }\end{array}$ & $\begin{array}{l}\text { Wage } \\
\text { increase }\end{array}$ & $\begin{array}{l}\text { Time to release } \\
\text { funding }\end{array}$ & $\begin{array}{l}\text { Pollution from } \\
\text { electric } \\
\text { locomotives }\end{array}$ & Retirement rate & \\
\hline Locomotive emissions & Fuel price & Annual fund use & & Wage increase & \\
\hline $\begin{array}{l}\text { Locomotive operating } \\
\text { time }\end{array}$ & $\begin{array}{l}\text { Fuel piece } \\
\text { increase }\end{array}$ & Railway funding & & & \\
\hline & & Investment rate & & & \\
\hline
\end{tabular}


There are also economic, pollution, hiring and energy variables in the model that can be mathematically changed based on country specific data which are also summarized in Table 1 .

In the Latvia model, there are two policies that produce results from the model. One is the upgrade policy for the railway and the other is the policy demanding a change in electrical power production. The two policies influence but do not depend on each other.

The current policy in accordance with the EU has the target of a carbon neutral energy market by 2050 . In the national energy and climate plan of Latvia, the goal is to reach $50 \%$ of total energy from RES within 2030, the current status in Latvia is that the RES is covering $39 \%$.

According to a study conducted by scientists at the Riga Technical University, the energy demand in Latvia will increase by $1 \%$ each year [15]. This is also considered in the model as this influences the energy sector and policy.

In this model the railway is considered as a part of the energy increase variable as the energy demand from the railway is very dependent on multiple factors that are not included in the model. The energy part of the model also includes an estimate of the energy production over the relevant time span in order to understand how much of the energy is used for the railway and what effect fully electrified railway would have on the energy system in Latvia.

The policy that will change Latvia's railway structure the most is the amount of electrified railway tracks (in kilometres) and not the amount or type of locomotives. However, this research considers the cost of changing the locomotives as well as the time it will take to change them. This is done to get a better understanding of how the new policy will change the railway overall instead of just how many kilometres have been electrified.

As the railway policy depends on the renewable energy policy, the status of this policy is very important to the success for the railway policy. This will show how much pollution has been retracted from the railway sector and the energy demand that the railway needs to reach the policy goals.

The current policy of the railway is to upgrade the railway to an electric one. This is in the first instance for the railway going from Rīga to Krustpils, Krustpils to Daugavpils and Krustpils to Rēzekne. These are the main lines in Latvia's railway and the busiest ones. An electrification of these lines will electrify 308 kilometres of the west-east line. This upgrade will cut the cost for

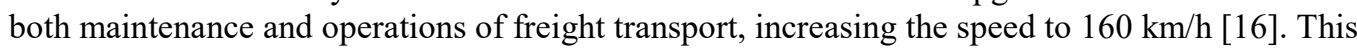
will improve the overall economy of the railway as well as reduce the pollution coming from this transport sector.

In the case study of Latvia, the starting point for the model is the year 1990, where there is an assumption on the locomotive stock in the railway as well as an assumption on how long the electrified railway was at that time. To start off, the model has 200 locomotives where the percentage of railway use is determined by the available electrified railway. As described previously, the already electrified railway is at $14 \%$, which is the starting point. When the policy is implemented in year 2030 (the year in which the new railway electrification project is set to be finished), the amount electrified railway in Latvia will be $30 \%$.

The model is developed from and explanatory model that highlights the problem model is going to show. The explanatory model in Fig. 3 shows how the emissions affect the emissions over time, adding them to the stock "Pollution from railway".

This variable gives us an indicator of how many locomotives can be changed in order to reach the goal of the policy. With the change rate dependent on the sub-models it will be dynamic towards changes in these models and behave according to the changes done in the testing phase.

Seven different scenarios have been developed for the Latvian case study and are summarized in Table 2 . 


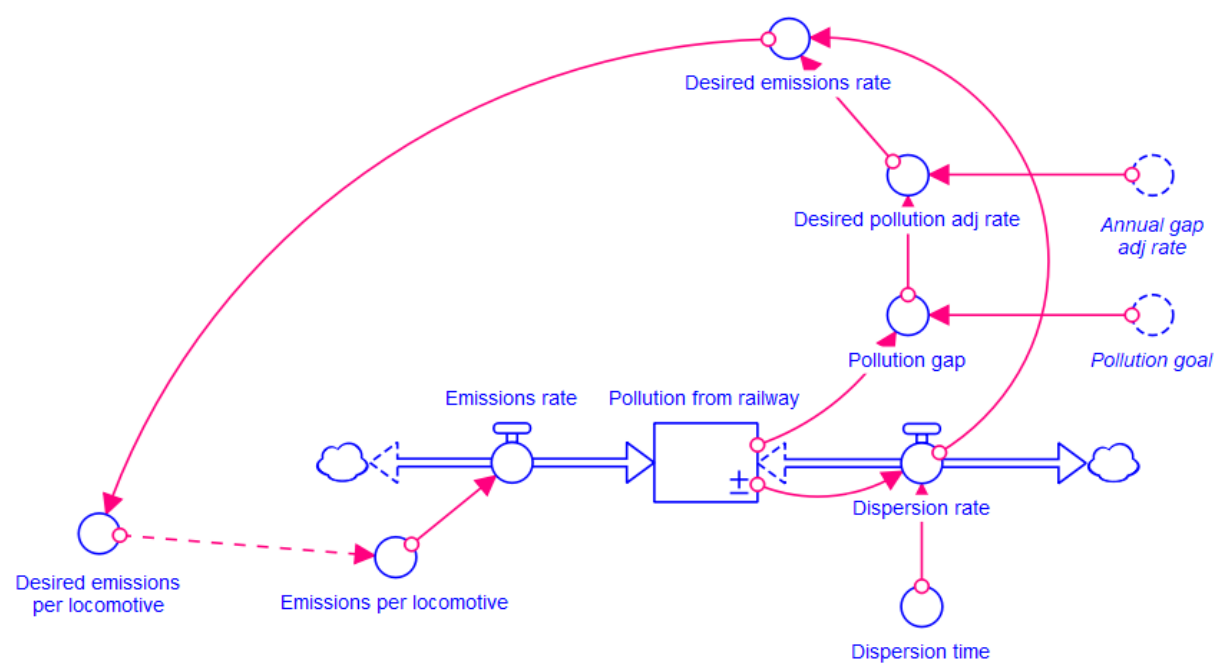

Fig.3. Explanatory model.

TABLE 2. DesCRIPTION OF SCENARIOS UTILIZED IN THE MODEL

\begin{tabular}{|c|c|c|}
\hline Scenario & Main factors & Description of scenarios \\
\hline 1 & $0 \%$ electrification & $\begin{array}{l}\text { Policy switch in the model is turned off (i.e., no policy is } \\
\text { implemented), giving the model the same results as before the } \\
\text { potential policy is implemented. In this scenario nothing changes, and } \\
\text { everything stays the same as it is now, considering that the railway } \\
\text { electrification project was cancelled in spring } 2020 \text {. }\end{array}$ \\
\hline 2 & $30 \%$ electrification & $\begin{array}{l}\text { The original electrification policy ( } 30 \% \text { of the railway is electrified) } \\
\text { switch is turned on (i.e., the policy is implemented) with the variables } \\
\text { described above. }\end{array}$ \\
\hline 3 & $60 \%$ electrification & $\begin{array}{l}\text { Electrification of } 60 \% \text { is introduced, increasing the electric } \\
\text { locomotives accordingly. This scenario is run with the desired funding } \\
\text { as funding to accommodate the increased need for funding that will } \\
\text { occur during the simulation. }\end{array}$ \\
\hline 4 & $100 \%$ electrification & $\begin{array}{l}\text { The railway is changed to } 100 \% \text { meaning that the locomotives also } \\
\text { will change towards } 100 \% \text {. The funding is also the desired funding in } \\
\text { this scenario. }\end{array}$ \\
\hline 5 & $\begin{array}{l}30 \% \text { electrification }+ \\
\text { RES }\end{array}$ & $\begin{array}{l}\text { The results in this scenario have a prerequisite of a fully renewable } \\
\text { energy sector giving the electric locomotive emissions only from } \\
\text { transfers, mostly PM. This will reduce emissions from the locomotives } \\
\text { even further. The railway will be electrified by } 30 \% \text {. }\end{array}$ \\
\hline 6 & $\begin{array}{l}60 \% \text { electrification }+ \\
\text { RES }\end{array}$ & $\begin{array}{l}\text { This scenario has the same assumptions as scenario } 5 \text { regarding } \\
\text { emissions from electric locomotives. The only thing that has been } \\
\text { changed in this scenario is the railway electrification up to } 60 \% \text {, } \\
\text { giving a further increase in electric locomotives and a decrease in } \\
\text { emissions. As in scenario 3, the funding is the desired funding. }\end{array}$ \\
\hline 7 & $\begin{array}{l}100 \% \text { electrification + } \\
\text { RES }\end{array}$ & $\begin{array}{l}\text { This is s a scenario where the pollution from the electric railway is } \\
100 \% \text { tank-to-wheel (TTW) instead of well-to-tank (WTT). Including } \\
\text { the desired funding as basis for the funding of the policy. }\end{array}$ \\
\hline
\end{tabular}


In the scenarios where the only thing that is changed is emissions per tonne, the only results that change are the emissions. In the scenarios where the railway is further electrified, the desired funding has been used to feed the model with funding data. This is to give the scenarios optimal conditions and not to hinder the change from diesel to electric locomotives.

\section{RESUlts}

In scenario 1, the locomotives do not change either and the number of electric locomotives is the same 28, while the diesel locomotives are 172. The results are reflected in Fig. 4 showing that the pollution is still at 43.5 billion pollution units (PU).

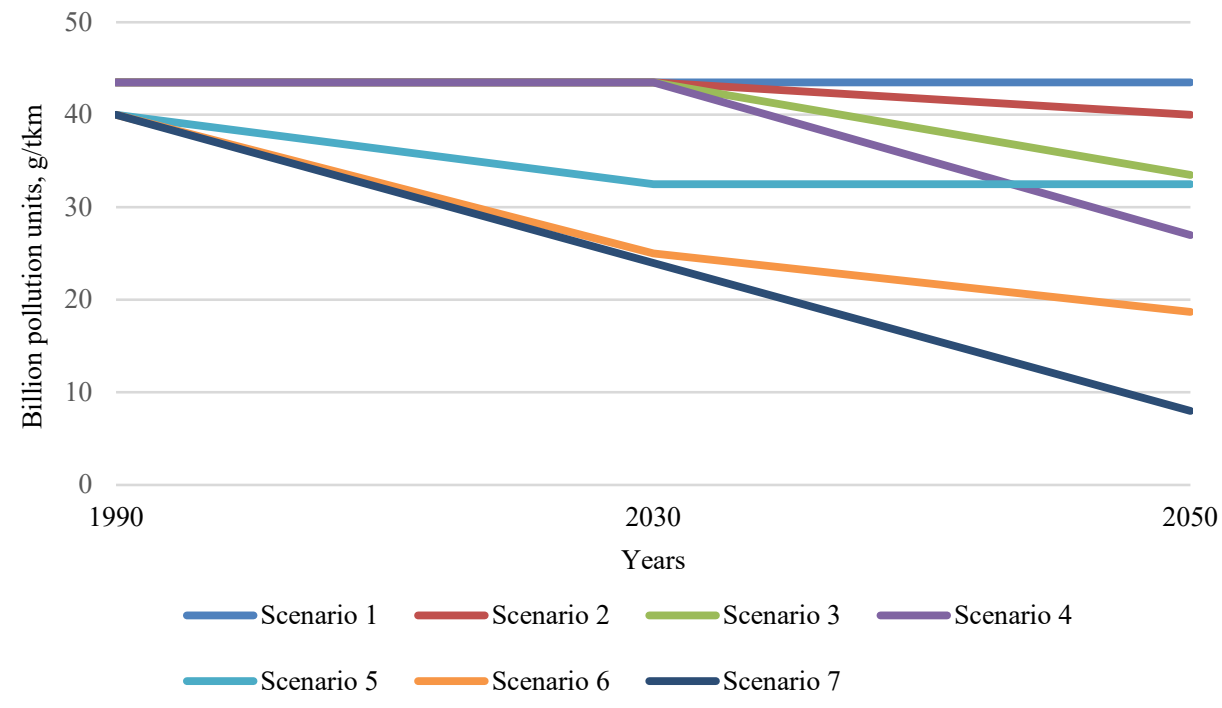

Fig. 4. Pollution units in all seven scenarios.

In scenario 2, the variables mimic the previous Latvian proposal for the new railway. The pollution from the railway drops significantly - from 43.5 billion PU to 40 billion PU, this is a drop of $8.05 \%$ (Fig. 4). It is important to remember that in this scenario, the energy sector has not been incorporated into the model giving the electric locomotives a fuel source that is fossil.

With the reduction in pollution also comes an increase in electric locomotives and by $204016 \%$ of the total locomotives have been changed from diesel to electric and that is the maximum amount when $30 \%$ of the railway is electrified, increasing the locomotives from 28 to 60 . The model also shows an increase in workers employed as 5 workers are needed to get one locomotive operation within 1 year.

When scenario 3 is implemented (60\% electrification), emissions dropped further to 33.5 billion tonnes PU, which is a $22.99 \%$ decrease. In 2046 there would be more electrified locomotives (121) than diesel fuelled (79). The desired funding changes depending on how much of the railway is electrified. The funding increases from approximately EUR 26.5 million to EUR 53 million once the policy is over.

Scenario 4 comes with $100 \%$ electrification, which means that eventually all locomotives become electric. In the case where the railway is electrified more than the original policy which 
is $30 \%$ electrification there is a need for more funding, as the original budget supports upgrades for EUR 440 million. Therefore, the desired extra funding is in the model to take account for future upgrades where the necessary extra funding must be added. Here pollution decrease to 27.4 billion PU in 2070 and it is expected that these values will continue to drop as the electric locomotives continue to change after the policy has ended. In this scenario, the number of workers increases to 22 .

The desired funding in Scenario 4 is EUR 136 million within the first year. This gradually decreases to EUR 68.7 million when the policy reaches the end in 2050 .

In the final three scenarios, the energy supply for the locomotives is "tank-to-wheel", simulating full renewable energy usage, giving the locomotives only pollution from transit. In this case, the renewable energy reduces the starting value for all the electric locomotives, which gives the model a starting value at 40 billion PU. In scenario 5, the pollution would drop to 32.5 billion PU (with a $30 \%$ electrification). The emissions from the diesel locomotives are responsible for most of the pollution coming from the railway and when the railway has been upgraded to electric, the pollution from the diesel sector drops significantly.

In scenario 6 (60\% electrification), the emissions for the electric locomotives are "tank-towheel" and for the diesel locomotives "well-to-wheel". When the supply chain is fully based on renewable energy sources and $60 \%$ electrified, emissions drops from 40 billion PU to 18.7 billion $\mathrm{PU}$ and, as in the previous scenario, diesel emissions drop significantly. The decrease of emissions continues steadily throughout the time-period of the policy, as well as some years after the policy has ended. When the policy is turned on the funding matches with the desired funding making the model conditions optimal. The employment reaches a peak in 2035 , when the employment is 34 workers.

Finally, in scenario 7 the railway is $100 \%$ electrified and energy supply is fully renewable. As could be expected, here the emissions have been reduced the most. The emissions drop according to the locomotive changes, the emissions start at 40 billion PU and drops under 10 billion PU in 2050. The emissions from the diesel locomotives also drop alongside the locomotive changes.

The employment peaks in 2035 with 33 new employed workers. When the policy stops in 2050, the worker employment rate is 25 workers. The funding in this scenario shares a pattern with the other scenarios where the desired funding has been used as a feed for the actual funding. Where the funding is covered during the policy time and increase depending on how much of the railway that has been electrified.

\section{Conclusions}

Different scenarios of the system dynamics modelling provided a rather wide range of results showing the real importance of two influential policies - electrification of the railway and switching over to usage of fully renewable energy.

As the results showed, when looking from the perspective of climate change and the possibilities to reduce that, it would be enough to implement scenario 2 in order to already decrease the pollution units by more than $8 \%$ that can be reached already before 2050 , which is the year for the major future climate targets.

It's important to understand that all the reviewed scenarios (besides the first one) not only provide climate benefits, but also impact the economy both from the side of investments, as well as employment and indirect economic benefits. Especially in these challenging times of international crisis, it is very topical to discuss future investments for the benefit of economic recovery. 
Although scenarios 5 to 7 are very hypothetical, they are excellent tools for showing how renewable energy policy positively affects pollution. However, from a more realistic perspective, scenarios 2 and 3 are both beneficial for the climate and less financially and politically intensive. Especially scenario 2 is very realistic considering that it is based on actual government plans, which are now seemingly cancelled, but hopefully will be introduced again.

The scenarios using full renewable energy policy could be further researched in the future providing a few softened versions, where the renewable energy in Latvia is at the $70 \%$ or $80 \%$ goal, which would have a greater potential for being implemented in state policy.

Overall, system dynamics modelling better explains the benefits of future policies and gives a good understanding of the possibilities and best choices considering the current economic situation and the aspects linked to that.

\section{ACKNOWLEDGEMENTS}

The research is funded by the Ministry of Economics of the Republic of Latvia, project "Sustainable and renewable transport policy formulation in Latvia (4muLATe)", project No. VPP-EM-2018/AER-2-0003.

\section{REFERENCES}

[1] European Commission. Dzelzceḷu kravu pārvadājumi ES: pareizais ceḷš vēl nav atrasts. Publications Office of the EU, 2016. (In Latvian). https://doi.org/10.2865/796882

[2] Central Statistical Bureau of Latvia. Dzelceḷa kravu pārvadājumi. (In Latvian). [Online]. [Accessed 30.11.2019.]. Available: https://www.csb.gov.lv/lv/statistika/statistikas-temas/transports-turisms/transports/tabulas/tr200c/kravuparvadajumi-dzelzcela-transporta

[3] University of Latvia. Latvijas Dzelzceḷš kravu pārvadājumu tarifa samazināšanas meklējumos. 2018. (In Latvian). [Online]. [Accessed 23.11.2019]. Available: https://www.jf.lu.lv/en/par-mums/ul-media/news/detailedview/t/43463/

[4] Porubova J., Bazbauers G. Analysis of Long-Term Plan for Energy Supply System for Latvia that is $100 \%$ Based on the Use of Local Energy Resources. Environmental and Climate Technologies 2010:4(1):82-90. https://doi.org/10.2478/v10145-010-0022-7

[5] International Energy Agency. $\mathrm{CO}_{2}$ emissions per tonne-kilometer in the EU, 2015. [Online]. [Accessed 01.12.2019.]. Available: https://www.eea.europa.eu/data-and-maps/figures/specific-co2-emissions-per-tonne-2

[6] Barisa A., Rosa A. A system dynamics model for $\mathrm{CO}_{2}$ emission mitigation policy design in road transport sector. Energy Procedia 2018:147:419-427. https://doi.org/10.1016/j.egypro.2018.07.112

[7] Liobikienė G., Butkus M. The European Union possibilities to achieve targets of Europe 2020 and Paris agreement climate policy. Renewable Energy 2017:106:298-309. https://doi.org/10.1016/j.renene.2017.01.036

[8] Egging R., Tomasgard A. Norway's role in the European energy transition. Energy Strategy Reviews 2018:20:99101. https://doi.org/10.1016/j.esr.2018.02.004

[9] Okpala et al. A review of modelling as a tool for environmental impact assessment. IREJEST 2013:39-46.

[10] Forrester J. W. System Dynamics - The next fifty years. System Dynamics Review, 2007. https://doi.org/10.1002/sdr.381

[11] Locmelis K., Blumberga A., Bariss U., Blumberga D. Energy policy for energy intensive manufacturing companies and its impact on energy efficiency improvements. System dynamics approach. Energy Procedia 2017:128:10-16. https://doi.org/10.1016/j.egypro.2017.09.005

[12] Kim Y-K. et al. Country-specific greenhouse gas emission factors of diesel-electric locomotive in Korea. Transportation Research Part D: Transport and Environment 2017:57:74-83. https://doi.org/10.1016/j.trd.2017.09.009

[13] Barisa A., Rosa A. Scenario analysis of $\mathrm{CO}_{2}$ emission reduction potential in road transport sector in Latvia. Energy Procedia 2018:86-95. https://doi.org/10.1016/j.egypro.2018.07.036

[14] $\mathrm{CO}_{2}$ European Emission Allowances. Markets Insider. 2020. [Online]. [Accessed 05.07.2020.] Available: https://markets.businessinsider.com/commodities/co2-european-emission-allowances

[15] Report of research project - Assessment on the use of renewable energy resources in Latvia until 2020. Riga Technical University, 2008.

[16] European commission. The EU invests in a faster, more efficient rail network in Latvia. Brussels, 2019. 